\title{
NAVEGAR POR ESPACIALIDADE E PERCURSOS: UM SIDERAL GUIA DE TERRITORIALIDADES
}

NAVIGATE BY SPACE AND ROUTE: A SIDERAL TERRITORIALITY GUIDE

Marcelo Calderari Miguel

Especialista em estatística, Universidade Federal do Espírito Santo, Brasil. Pesquisador. Programa Institucional de Iniciação Científica e Tecnológica, Ufes, Brasil.

E-mail: marcelo.miguel@caixa.gov.br

https://orcid.org/0000-0002-7876-9392

\section{O Terror Do Bicho Terra, Um Rol De Percursos E Espacialidades}

Tenho visto é claro, em minhas recordações muitas sombras.

Minha memória alerta o quanto pode ser escuro alguns lagos profundos.

No lado de cá tenho todo sofrimento do mundo, cachoeira de lamentos.

No lado de lá tenho um duplicado oceano, geminações de ressentimentos.

Como sou rancoroso... Cultivei uma frondosa magoa que persiste no tempo.

Ah como é tenebroso o lado obscuro do ser, melhor não conhecer essa espacialidade.

E percorre o agora, meus olhos se alargam e os joelhos se dobram em dor; que pavor!

Lado a lado com o sombrio tudo é sofrido; a pele se rasga de arrepio e frio.

A vida torna-se um cuspido pântano, um olho-d'água que reflexos de luz falta.

Reza lenda que cavar tal senda é como derrocar a retidão de 'Adão'. Mas que deboche. 


\section{Encairelar Colóquios, Adsumus}

O sentimento 'nostálgico' olhou para o tempo e indagou:

A profunda e indefinida tristeza é causada pela 'ausência' de algo ou alguém?

Então, a suprema desgraça se encontra na 'distância' de uma era passada ou a vigente?

O sentimento 'melancólico' olhou o tempo e perguntou: É normal sentir a 'saudade' da terra natal, do lar e das coisas que me são familiares? O que se cala por trás de tanta ironia e da 'solidão' do espírito?

Talvez - diz o tempo - a vida seja um plainar feminista.

Sei que a tristeza, tristura, melancolia, nostalgia, apatia são efêmeras companhia.

No fim nada remi o gênero! Seja selvagem, artista, camarada ou turista tudo na vala acaba. 


\section{Cosmopolita E Provinciano: Consolidar Territorialização, Pautar Territorialidades}

Tempos atrás não existia a Grande metropolitana Vitória.

Havia a Vitória pequena, Menina...

No sopé do Convento havia a Vila Velha, a qual pendia ser vilarejo dormitório.

Havia Vila Velha, Esposa incluiria...

Já Viana abrigará a arvore de Jabaeté, nos resquícios do sertão do Santo Agostinho.

Havia Viana, uma longínqua Tia...

A Serra estava lá na serra, tida à silhueta do Mestre Álvaro, remota por ventura.

Havia a sede Serra, Moçinha...

E Guarapari, a saúde que vem do mar, uma garça vermelha, a rubra proteção da ameaça.

Havia Guarapari, tão jeitosa Filha...

O fim da trilha era o Fundão, eis o Reis Mago Balneário, a grande Praia e o Timbuí.

Havia Fundão, Avó semota diria...

E Cariacica era a vinda do branco homem, Portal Maciço Moxuara, a boa cachaçaria!

Havia Cariacica, a Prima e que prima...

Cariacica, Fundão, Guarapari, Serra, Viana, Vila Velha e Vitória do pó preto... Cidades.

Terna terra, Grande Vitorinha é: Prima, avó, filha, moça, tia, esposa, menina... Mulher! 


\section{Coruscante Arvorecer De Uma Assembleia}

Japa-mala um ária de sussurros.

Tem origem sânscrita a composta palavra.

Um cordão sagrado feito de contas; cento e oito se conta.

É puro ato de sussurrar ou murmurar repetidos mantas, divindades.

É marcado artesanal que metrifica a matemática da mentalização espiritual.

Nele vejo artefato para a divinal devoção, rosário de orações reconhecidamente.

A yogui filosofia reporta circuito repetido do mantra, um estágio superior alcança-se.

Não são os entremeios ou ponteira que garantem a iluminação, mas efeito está no sentir.

A busca de a evolução espiritual no prosar do destino advém na busca do melhor de nós.

Assim fluente e consciente do chamamento transcendental minha alma se eleva pura.

Cada vez que o manta divinal se mentaliza, puxa-se uma conta, sensação se recria.

Assim regurgito meu ego e melodicamente aqueço meu humano ser extraviado.

$\mathrm{Na}$ rica rítmica sintonia dos modilhos, alma ratifica e retificam-se evocais.

Jamala invocais, extensão vocais nas pregas nunca antes olvidadas.

Ascensão do balão se dá pelo atmosférico aquecimento do ar, se reprisar em mantra, a menos densa e mais eleva dádiva.

Para efeito surtir, a meditação crebra deve ser.

Se os sociais fatos rompem crebramente,

os limites da legalidade inflexíveis.

E assim rojo a pergunta:

Qual é seu mantra?

Diante do Arvoredo de 'rudraksha' temos múltiplas espécies:

Agradáveis aos olhos, Alta, Altiva, Baixa, Bem regada, Boa,

Caída, Conhecidas pelo seu fruto, Da floresta, Da Sabedoria.

Da terra, 'Da Vida', De outono, Do campo e 'palmas batem'.

Do conhecimento, Do Éden jardim, Do senhor, Que andam.

Frondosas, Frutíferas, Grandes, Junto às águas, Majestosas.

Muito altas, Nativas, Plantadas à 'beira de águas correntes'.

Plantadas 'junto às águas', Que 'não' dão bom fruto, Secas.

Que dão frutos com sementes, Ruins, Verdes ou Verdejantes. 


\section{Os Extremos Da Cidade Entre Itinerários, Canchas E Cais}

A ilha do mel ainda fica alguns centímetros acima da linha do mar.

Contarão os contemporâneos e os extemporâneos que exagero.

Mas Vitória era mais ou menos assim... Vitórinha.

As alunas do Carmo - porque havia o Carmo - galgavam elegantes uniformes.

Na Praça Costa Pereira, os bondes - porque havia bondes - era chique passagem.

Do lado oposto, além do Glória - que havia Glória - esticava-se a Avenida Capixaba.

A Esplanada da Capixaba vira aterro - que havia terra - aterrando o fundo mar afundo.

A ilha do mel porque mudastes, acima da vazão do oceano... Dirão então:

Lá foi a Maria Tomba-Homem, a Casa Branca e a Verde, o tempo que Camburi era apenas Camburi e nem tinha esses jardins que se dizem por ai.

A vida era simples, domingueiras regatas, Álvares Cabral topando o Saldanha da Gama. A vida era metódica, poucas óticas e farmácias, no máximo duas para cada olho. A vida sutil nas ruas de paralelepípedos cantava-se cirandas, plantava-se bananeira. 


\section{Um Cume Perpetuar De Desenvolvimento E Grandeza: Raro Recanto Do Sul}

No ano que nasci surgiu 'o Espírito Santo na história, na lenda e no folclore'...

Quanta coisa li ali, a divinal e santa mão cantava os notáveis monumentos.

Um do mais que impressionava era sobre a natureza - O Frade e a Freira.

Hum... Estas duas e imensas 'penedias' encimara contorno ao verdejante 'cerro'.

Caprichado natural esculpi-se no 'granito' religiosos perfeitos, num montante ensejo.

E com mínimos detalhes a estupenda formação rochosa retrata em épocas remotas,

Viveram naquela paragem um frade e uma freira impossibilitados de união concluir.

E Deus por piedade, vendo os fiéis nos votos que professaram - converteu-os em roca.

Assim granito que tanto eterniza, acima dos apuros imortaliza o castiçal e santo amor.

Trabalha e confia que apesar dos penhascos da vida - o Senhor honra toda fraga penha.

Eis a bela Itapemirim, que se faz notável e histórica; Rota da Costa, da Imigração e de lendas. 


\section{Pássaro De Fogo: Libertar De Amor, Relações Que Perpetua No Tempo}

Reza a lenda que sitia as cidades de Cariacica e Serra que existiam duas rivais tribos.

O chefe da tribo que sitiava os domínios de Cariacica teve uma filha lindíssima.

Tal preciosidade veio a ter um 'crush' por um arrojado guerreiro da tribo rival.

Eis a origem de Rudá, o deus tupi do amor, manda aos céus uma avícola curial.

E a fantástica ave via o sofrimento do casal; amor proibido e nada trivial.

Decidido a ajudar, o pássaro leva de 'lá pra cá' e ‘cá pra lá' escritural recado.

Marcando encontro, os jovens mesmo tendo o sobrenatural ao seu lado foram revelados.

Dizem as más línguas que um dos chefes tribal irado rogou pedido um xamã infalível.

Um poderoso feitiço predizia que amantes jamais se encontrassem em dia algum da vida.

O velhaco curandeiro impetrou aos deuses uma eficaz provisão, um tanto magistral.

Os deuses severos e primorosos prenderam os jovens amantes em prisão de pedra fatal.

E o jovem guerreiro nesse meio-tempo foi materializado no monte Mestre Álvaro.

A jovem princesa transformada igualmente na exemplar pedra irmã, Moxuara.

Lamentavelmente e infinitesimalmente jamais poder-se-ão tocar ou falar novamente.

Ambos condenados insensatamente a estar um de frente ao outro por eternais tempos!

A brava gente, dessas tribos, pedidos de compaixão aos céus rogaram e, veio à outorga:

Na graça da magia e encanto uma vez por ano os amantes da pedra-prisão se libertaram!

Eis que 24 de junho a ave se converte em chama; rasga o empíreo, indo ensejos apostolar. 